\title{
Numerical investigation of hydrogen charging performance for a combination reactor with embedded metal hydride and coolant tubes
}

\author{
Maha Bhouri*, Inga Bürger, Marc Linder \\ Institute of Technical Thermodynamics, German Aerospace Center (DLR), D-70569 \\ Stuttgart, Germany
}

\begin{abstract}
A two-dimensional model investigating the hydrogen charging process in a combination reactor filled with both $\mathrm{LaNi}_{4.3} \mathrm{Al}_{0.4} \mathrm{Mn}_{0.3}$ and $2 \mathrm{LiNH}_{2}-1.1 \mathrm{MgH}_{2}-0.1 \mathrm{LiBH}_{4}-3$ wt.\% $\mathrm{ZrCoH}_{3}$ materials has been developed. The selected configuration is a cylindrical reactor of 32 $\mathrm{cm}$ of diameter where the $\mathrm{MeH}$ is filled in annular tubes separated from the complex hydride bed by a gas permeable layer. The diffusion of hydrogen towards the two storage media is ensured by filters embedded in the middle of the $\mathrm{MeH}$ tubes whereas the coolant tubes are placed in the centre of their triangular arrangement. Simulation results have shown that the charging process depends on the $\mathrm{MeH}$ reaction heat required for the initiation of the $\mathrm{CxH}$ reaction as well as the heat management once the complex hydride starts to store hydrogen. High hydrogen storage rates and short refueling times can be obtained by increasing the number of $\mathrm{MeH}$ and coolant tubes and ensuring an efficient heat removal at the peripheral area of the $\mathrm{CxH}$ media. A refueling time of $3 \mathrm{~min}$ is achieved for an optimum configuration of $49 \mathrm{MeH}$ tubes and 96 coolant tubes while increasing the thermal conductivity of the $\mathrm{CxH}$ media to $3.5 \mathrm{~W} /(\mathrm{m} \mathrm{K})$. Such a result could make the identified optimum configuration as a suitable hydrogen storage system for fuel cell forklift trucks since it meets the requirements of this application in terms of weight and size.
\end{abstract}

\section{Keywords}

Complex hydride

Metal hydride

Combination reactor

Embedded coolant tubes

Refueling time

2D simulation

*Corresponding author. Tel.: +49 711 6862-531; Fax: +49 711 6862-632

E-mail address: maha.bhouri@dlr.de 


\section{Introduction}

As the international community raises its ambitions to tackle climatic and economic issues related to the use of fossil fuels, serious efforts are devoted to the building of the hydrogen economy. Firstly, research and development programs have been directed to the hydrogen-fueled light duty vehicles market. This was supported by the technical advances in fuel cell area. Nevertheless, there remain multiple challenges to be overcome before the deployment of hydrogen fuel cell cars at a commercial scale [1].

As a second step along this path, the U.S. Department of Energy (DOE), in collaboration with the National Renewable Energy Laboratory (NREL) and Sandia National Laboratory (SNL) has worked to identify early adoption markets with less stringent technical challenges than automobile sector. It has been found that specialty vehicles, stationary back-up power and portable applications present a huge market potential for the near-term development of the hydrogen technology [2], [3]. For specialty vehicles, hydrogen powered fuel cell forklifts have significant benefits over existing technologies such as fossil fuel powered trucks and battery electric forklifts [4], [5].

The most common battery used in the materials handling applications is the lead acid battery. The related electric forklifts are primarily designed for indoor use in order to minimize exhausts and noise, which is mandatory in such working environment. However, the long refueling time is the major issue of this technology. Indeed, the time required to change the battery is from 5 to $15 \mathrm{~min}$ for an automatic operation and up to $45 \mathrm{~min}$ for a manual one. Then, it takes 8 hours to charge the battery and the same time interval to cool it down. This implies that a 24 hours/7 days operation will require three batteries for each forklift. Furthermore, these operations involve the move of very heavy elements and require large battery rooms under controlled atmosphere, with the risk of hazardous materials presence. In addition, battery electric forklifts suffer from a loss of productivity as the battery discharges and show low performance under freezing conditions. Such problems could be addressed by the transition to the hydrogen powered fuel cell forklifts. Consequently, several demonstration projects have been undertaken to bring fuel cell forklifts to a commercial stage and to implement the necessary infrastructure [6-11].

The cost of the hydrogen storage and the saving in the refueling time are among the performance parameters being considered during these projects. For the majority of fuel cell forklifts tested under North American and European pilot programs, the hydrogen is supplied at pressures of 350 and 700 bar [7], [10]. This corresponds to a refueling time of less than $5 \mathrm{~min}$ and eliminates the time consumed by the battery change-out. The choice of the pressurized hydrogen storage technique is supported by the development of the related hydrogen refueling equipment, although the infrastructure is still expensive. Furthermore, the use of compressed gaseous tank results in lighter hydrogen component system compared to the lead acid battery. Hence, additional ballast is incorporated to compensate this weight loss [7].

Solid-state hydrogen storage systems, showing poor gravimetric capacities in the case of light duty vehicles could be a suitable choice for applications such as forklift trucks since they provide weight, safety and low pressure-cost benefits over compressed 
gaseous storage systems. In this context, some models of fuel cell forklifts based on solid-state hydrogen storage have already been tested or are under development [7], [11]. One of the first forklift trucks carrying hydrogen in a metal hydride tank has been introduced in Germany in 2000, as part of a joint project between Linde Group and Siemens AG's Power Generation Group [7]. The selected storage material is a titaniumbased hydride with a charging time of 10 min. Over the past few months, researchers from Sandia National Laboratories and Hawaii Hydrogen Carriers are working together on the design of a solid-state hydrogen storage system filled with a Mischmetal-nickelaluminium alloy [11]. The developed reactor will be integrated into the forklift fuel cell pack with the goal to show the potential storage time, cost and market growth advantages. Similarly, a wide variety of low-temperature metal hydrides extensively studied in hydrogen light duty vehicles projects could find their applications on-board forklift trucks.

Complex hydrides have high hydrogen storage capacities up to $10 \mathrm{wt} . \%$. and could be cost competitive compared to some metal hydrides [12]. However, their use is hindered by their slow kinetics at practical operating conditions. Recently, a new complex hydride reactor concept has been developed to overcome this weakness. It is based on the combination of $\mathrm{LaNi}_{4.3} \mathrm{Al}_{0.4} \mathrm{Mn}_{0.3}$ and $\mathrm{Li}-\mathrm{Mg}-\mathrm{N}-\mathrm{H}$ materials. The investigation of the charging process has proven the possibility to reduce the time required for the initiation of the complex hydride reaction by $600 \mathrm{~s}$ while starting the loading of hydrogen at room temperature [13]. In this paper, we investigate the capability of such a complex hydride reactor concept to meet the requirements of fuel cell forklift applications in terms of refueling time and system weight and size. In the first part, the charging performance of a hydrogen storage system with embedded filters, metal hydride and heat exchanger tubes is assessed through the numerical study of different reactor configurations. Thereafter, the weight and volume of the final selected reservoir design are determined in function of the fuel cell forklifts energy requirements.

\section{Model formulation}

\subsection{Description of the studied configuration}

In previous studies [13], the possibility of accelerating the charging process of the complex hydride, $2 \mathrm{LiNH}_{2}-1.1 \mathrm{MgH}_{2}-0.1 \mathrm{LiBH}_{4}-3 \mathrm{wt}$. $\% \mathrm{ZrCoH}_{3}$ through its combination with the metal hydride, $\mathrm{LaNi}_{4.3} \mathrm{Al}_{0.4} \mathrm{Mn}_{0.3}$ has been proven. The studied configuration is a $50 \mathrm{~g}$ tubular reactor where a gas permeable separation layer (GPSL) ensures the indirect contact between the two storage media: the metal hydride at the centre of the tube, surrounded by the complex hydride. The combination reactor, initially at room temperature, is filled with hydrogen at 70 bar. Since the $A B_{5}$ material, $\mathrm{LaNi}_{4.3} \mathrm{Al}_{0.4} \mathrm{Mn}_{0.3}$ is able to absorb hydrogen very quickly at these ranges of temperature and pressure, its reaction heat ensures the heat up of the complex hydride bed to temperatures above $130{ }^{\circ} \mathrm{C}$. Furthermore, based on the kinetics measurements of the Li-Mg-N-H material at 70 bar, it has been shown that temperatures above $130{ }^{\circ} \mathrm{C}$ are required for achieving 
high hydrogen loading rates [14]. Accordingly, in a combination reactor, the complex hydride charging process is initiated without the need of external heat source integration. The numerical investigation of the combination reactor charging process [13] has shown that the metal hydride, $\mathrm{LaNi}_{4.3} \mathrm{Al}_{0.4} \mathrm{Mn}_{0.3}$ reaches its saturated state after only $10 \mathrm{~s}$ transferring then its reaction heat towards the complex hydride media. As a result, the Li-Mg-N-H material starts to absorb hydrogen in the region close to the GPSL and a reaction front is developed from the core to the annulus of the reactor. As the reaction proceeds, the complex hydride reaction heat is removed by the heat transfer fluid circulating through the reactor wall. Overall, the time required for the initiation of the complex hydride reaction is reduced by $600 \mathrm{~s}$ although the combination reactor charging process starts from room temperature.

A subsequent study of the same configuration with different thicknesses of the $\mathrm{MeH}$ and $\mathrm{CxH}$ materials has proven that the dimensions of the two storage media should be chosen carefully in order to avoid slow $\mathrm{CxH}$ hydrogen charging process due to kinetics or heat transfer limitations [15]. A hydrogen charging time of $387 \mathrm{~s}$ has been achieved for a combination reactor of $10 \mathrm{~mm}$ and $12.5 \mathrm{~mm}$ for the metal hydride and complex hydride bed thicknesses, respectively. The scale up of such a configuration for the storage of higher amount of hydrogen $\left(\geq 1 \mathrm{~kg} \mathrm{H}_{2}\right)$ will result in a multi-tubular reactor design.

In this paper, we discuss the capability of a large cylindrical solid hydrogen storage system based on the advanced reactor concept described above to achieve fast hydrogen loading rate and short charging time. The motivation to select such a configuration is to present a comparison with the large pressurized hydrogen cylinders used for vehicles applications, in particular forklift trucks, in terms of refueling time as well as weight and size requirements. Accordingly, the dimensions (a diameter of $32 \mathrm{~cm}$ ) of the studied reactor have been chosen comparable to those of gaseous storage tanks studied in [16], [17].

In this context, the extensively studied configuration of the cylindrical reactor with embedded multiple filters and heat exchanger tubes has been selected [18-20]. Similar to the previous studies [13], [15], the two storage media, $2 \mathrm{LiNH}_{2}-1.1 \mathrm{MgH}_{2}-0.1 \mathrm{LiBH}_{4}$ $3 w t . \% \mathrm{ZrCoH}_{3}$ and $\mathrm{LaNi}_{4.3} \mathrm{Al}_{0.4} \mathrm{Mn}_{0.3}$, have been selected as reference materials and are abbreviated in the following text as $\mathrm{CxH}$ and $\mathrm{MeH}$. Three different designs of the hydrogen storage system have been considered as shown in Fig. 1.

To adapt the multiple tubes and filters configuration to the present, the $\mathrm{MeH}$ material is filled into annular tubes distributed uniformly through the complex hydride bed in an octagonal arrangement. Since the $\mathrm{AB}_{5}$ material should react first, the hydrogen injection tubes are at the centre of the $\mathrm{MeH}$ media and the hydrogen diffuses towards the complex hydride material through the gas permeable layer separating the two storage media. The coolant tubes are placed at the centre of the triangle arrangement formed by the three connected hydrogen injection tubes to remove the released $\mathrm{CxH}$ 
reaction heat since the $\mathrm{CxH}$ material starts to react mainly at the region close to the $\mathrm{MeH}$ media.

The optimization of the hydrogen charging process depends on the amount of the metal hydride required to initiate the $\mathrm{CxH}$ reaction as well as the thermal management of the $\mathrm{CxH}$ reaction heat. Therefore, two alternatives are examined in this study

- Increasing the thickness of the MeH media, $\mathrm{d}_{\mathrm{MeH}}$ while keeping the same number of coolant tubes, as shown in Case 1, Fig. 1.

- Increasing the number of the MeH annular tubes while keeping constant their thickness, $\mathrm{d}_{\mathrm{MeH}}$. Accordingly, the number of hydrogen injection tubes and coolant tubes is increased as illustrated in Cases 1-3, Fig. 1.

For all the studied cases, the diameters of the large combination reactor and the hydrogen injection tubes are set constant whereas the one of the coolant tubes decreases with their increasing number. The details of the corresponding combination reactor geometries are summarized in Table 1.

\subsection{Governing equations}

The mathematical model describing the heat and mass transfer in the combination reactor includes the kinetics equations, the hydrogen mass balance and the energy balance of the two storage media. It is developed based on the following assumptions

- There is a local thermal equilibrium (LTE) between the MeH material, the CxH material and the hydrogen gas.

- The porosities of the complex and metal hydrides are constant.

- The thermo-physical properties of the two hydride beds are independent of the transformed fractions, the pressure and the temperature.

- The influence of the GPSL on heat and mass transport is neglected.

- The thermal contact resistance is neglected between the $\mathrm{MeH}$ bed and the hydrogen injection tubes and the $\mathrm{CxH}$ bed and the coolant tubes.

- The bulk temperatures of the heat exchange fluid and the hydrogen supplied to the bed are constant and uniform.

- The equation of state for hydrogen is given by the simplified van der Waals equation.

\subsubsection{Kinetics equations}

Reaction kinetics of both, metal and complex hydrides are determined based on their measured hydrogen charging rates under different conditions of temperature and pressure as described in [14].

The transformed fractions $x_{\mathrm{MeH}}$ and $x_{\mathrm{CxH}}$ for the two storage media are defined in function of the bed weight fractions of stored hydrogen, $w_{f, \mathrm{CxH}}$ and $w_{f, \mathrm{MeH}}$ as

$$
x_{\mathrm{MeH}}=\frac{w_{f, \mathrm{MeH}}}{w_{f, \mathrm{MeH}, \max }}
$$




$$
x_{\mathrm{CxH}}=\frac{w_{f, \mathrm{CxH}}}{w_{f, \mathrm{CxH}, \max }}
$$

and their temporal evolutions are expressed by the following equations

- MeH material

$$
\frac{\partial x_{\mathrm{MeH}}}{\partial t}=A_{a, \mathrm{MeH}} \exp \left(-\frac{E_{A, \mathrm{MeH}}}{R T}\right) \log \left(\frac{P}{P e q_{a, \mathrm{MeH}}}\right) \times\left(1-x_{\mathrm{MeH}}\right)
$$

- $\mathrm{CxH}$ material

$$
\frac{\partial x_{\mathrm{CxH}}}{\partial t}=\left\{\begin{array}{lc}
A_{a, \mathrm{CxH}, 1} \exp \left(-\frac{\left.E_{A, \mathrm{CxH}, 1}\right)}{R T} \frac{\left(P-P e q_{a, \mathrm{CxH}}\right)}{P e q_{a, C x H}} \times 0.33\right. & 0 \leq x_{\mathrm{CxH}} \leq 33 \% \\
A_{a, \mathrm{CxH}, 2} \exp \left(-\frac{E_{A, \mathrm{CxH}, 2}}{R T}\right) \frac{\left(P-P e q_{a, \mathrm{CxH}}\right)}{P e q_{a, C x H}} \times\left(1-x_{\mathrm{CxH}}\right) & 33 \% \leq x_{\mathrm{CxH}} \leq 100 \%
\end{array}\right.
$$

The equilibrium pressures $P e q_{a, \mathrm{CxH}}$ and $P e q_{a, \mathrm{MeH}}$ are based on the van't Hoff equation

$$
\begin{gathered}
P e q_{a, \mathrm{CxH}}=P_{0} \exp \left(\frac{\Delta H_{a, \mathrm{CxH}}}{R T}-\frac{\Delta S_{a, \mathrm{CxH}}}{R}\right) \\
P e q_{a, \mathrm{MeH}}=P_{0} \exp \left(\frac{\Delta H_{a, \mathrm{MeH}}}{R T}-\frac{\Delta S_{a, \mathrm{MeH}}}{R}\right)
\end{gathered}
$$

\subsubsection{Hydrogen mass balance}

The density of the hydrogen gas is calculated based on the simplified van der Waals equation

$$
\rho_{g}=\frac{P M_{H_{2}}}{[R T+(b-a / R T) P]}
$$

and the Darcy's law is used for the description of the hydrogen gas velocity

$$
\vec{v}=-\frac{\mathrm{K}}{\mu_{g}} \nabla P
$$

The hydrogen mass balance is given by

$$
\frac{\partial\left(\varepsilon \rho_{g}\right)}{\partial t}+\nabla \cdot\left(\rho_{g} \vec{v}\right)=-(1-\varepsilon) \dot{m}_{R}
$$

\subsubsection{Bed energy balance}

During the charging process of the two storage media, the convective heat transfer of the gas phase, the heat transfer by thermal conduction in gas and solid phases, the reaction heat source and the pressure work are considered. Accordingly, the energy equation can be written as

$$
\begin{aligned}
{\left[(1-\varepsilon) C_{p, b e d} \rho_{b e d}+\varepsilon C_{p, g} \rho_{g}\right] \frac{\partial T}{\partial t}=} & -C_{p, g} \rho_{g} \vec{v} \cdot \nabla T-\nabla \cdot\left(-k_{b e d} \nabla T\right) \\
& -(1-\varepsilon) \dot{m}_{R} \Delta H_{R}+\alpha_{v} T\left(\varepsilon \frac{\partial P}{\partial t}+\vec{v} \cdot \nabla P\right)
\end{aligned}
$$


$\dot{m}_{R}$ and $\alpha_{v}$ are the mass change of hydrogen and the general volumetric thermal expansion coefficient for real gases, respectively. They are expressed as

$$
\begin{gathered}
\dot{m}_{R}=\rho_{\text {bed }} w_{f, s, \max } \frac{\partial x}{\partial t} \\
\alpha_{v}=-\left.\frac{1}{\rho_{g}} \frac{\partial \rho_{g}}{\partial T}\right|_{P}
\end{gathered}
$$

2.2.4. Wall tube energy balance

The energy equation for the stainless steel wall tube is

$$
C_{p, \mathrm{~S} . \mathrm{S}} \rho_{\mathrm{S} . \mathrm{S}} \frac{\partial T_{\mathrm{S} . \mathrm{S}}}{\partial t}=-\nabla \cdot\left(-k_{\mathrm{S} . \mathrm{S}} \nabla T_{\mathrm{S} . \mathrm{S}}\right)
$$

\subsubsection{Initial and boundary conditions}

Initially, the $\mathrm{MeH}$ and $\mathrm{CxH}$ storage media are at a fully desorbed state. Their initial temperature and pressure are set to $22{ }^{\circ} \mathrm{C}$ and 1 bar.

To initiate the $\mathrm{MeH}$ charging process, the hydrogen pressure in the injection tubes increases exponentially to 70 bar, resulting in a pressure gradient which allows the gas to flow from the tubes into the metal and complex hydride beds.

At the same time, a heat exchange fluid flows through the stainless steel tubes at $130{ }^{\circ} \mathrm{C}$. This leads first to a temperature increase in the surrounding $\mathrm{CxH}$ media which promotes the initiation of the complex hydride reaction. Thereafter, the heat exchange fluid acts as a coolant once the $\mathrm{CxH}$ starts to absorb hydrogen. It should be noted here that the coolant temperature of $130{ }^{\circ} \mathrm{C}$ has been carefully chosen by taking into account the compromise between the efficient cooling of the $\mathrm{CxH}$ bed due to its exothermic reaction nature and the need to maintain it at a temperature above $130{ }^{\circ} \mathrm{C}$ in order to ensure high hydrogen loading rates as discussed in [14].

In most studies, an adiabatic boundary condition is applied at the wall of the hydrogen injection tube [18], [21]. However, an analysis conducted by Na Ranong et al. [22] revealed that applying such a boundary condition is not appropriate since it does not predict the cooling effect of the inlet hydrogen on the loading behavior. In this study, this aspect is described by applying a heat flux boundary condition at the $\mathrm{H}_{2}$ injection tubes wall

$$
-\vec{n} \cdot\left(-k_{\mathrm{MeH}} \nabla T_{\mathrm{MeH}}\right)=h_{H_{2}}\left(T_{H_{2}}-T_{\mathrm{MeH}}\right)
$$

The reaction heat released during the charging process of the $\mathrm{CxH}$ material is transferred towards the heat exchange fluid through the lateral stainless steel tube surface, whereas the external reactor wall is thermally insulated. Thus, a heat flux boundary condition is applied at each coolant tube wall

$$
-\vec{n} \cdot\left(-k_{\mathrm{S} . \mathrm{S}} \nabla T_{\mathrm{S} . \mathrm{S}}\right)=h_{\text {cool }}\left(T_{\text {cool }}-T_{\mathrm{S} . \mathrm{S}}\right)
$$


The metal and complex hydrides properties as well as the coolant conditions used in the mathematical model are summarized in Table 2.

\subsection{Numerical procedure}

The mathematical model presented above has been validated for a $50 \mathrm{~g}$ lab-scale tubular reactor [13]. Here, it is applied to the cylindrical reactor configurations depicted in Fig. 1. The modeled domains are taken as one-eighth of the cross sections due to symmetry considerations $\left(45^{\circ}\right)$. The commercial finite element software, COMSOL Multiphysics ${ }^{\circledR}$, version 4.4 , has been used to carry out the numerical study and mesh sensitivity tests have been performed for all the studied configurations especially at the complex hydride/metal hydride boundaries to accommodate high spatial temperature gradients during the initiation stage of the $\mathrm{CxH}$ reaction. As a result, the temporal evolution of temperature and amount of stored hydrogen related to the different selected configurations are compared in order to assess the charging performance of the combination reactor.

\section{Results and discussion}

\subsection{Effect of the MeH bed thickness}

As a first attempt to study the dependence of the charging process on the amount of the metal hydride that should be used, the configuration of a combination reactor equipped with $9 \mathrm{MeH}$ tubes and 8 coolant tubes has been selected. The thickness of the MeH bed, $\mathrm{d}_{\mathrm{MeH}}$ is varied from $0.7 \mathrm{~cm}$ to 1.7 and $2.7 \mathrm{~cm}$ (Cases 1.a-c, Table 1). The spatial evolutions of temperature and transformed fraction of hydrogen at different selected times are shown in Fig. 2.

For both metal and complex hydrides, the exothermic charging processes are controlled by the driving forces defined as the ratio and the difference between the charging pressure and their equilibrium pressures, respectively (see Eqs.(3)-(6)). If the heat of reaction is not efficiently removed, the equilibrium temperature can be reached implying that the equilibrium pressure is almost equal to the hydride bed pressure and the uptake of hydrogen can be delayed or even stopped. In such case, the hydriding process is thermally limited. Consequently, for a charging pressure of 70 bar, the MeH and $\mathrm{CxH}$ beds temperatures should not exceed the equilibrium temperatures of $295{ }^{\circ} \mathrm{C}$ and $230^{\circ} \mathrm{C}$, respectively in order to ensure fast hydrogen loading rates.

For the metal hydride bed, this thermal limitation is not observed. Indeed, for the three studied cases, the metal hydride reacts very fast, so that after $60 \mathrm{~s}$, the MeH media is the hottest region of the reactor with a temperature up to $250{ }^{\circ} \mathrm{C}$ and it is already saturated $\left(x_{\mathrm{MeH}}=1\right)$. The $\mathrm{MeH}$ reaction heat is then transferred to the $\mathrm{CxH}$ material initiating its loading process, and a reaction front growing from the $\mathrm{MeH}$ annular tubes to the surrounding $\mathrm{CxH}$ area can be observed $(\mathrm{t}=120 \mathrm{~s})$.

The MeH reaction heat released during the absorption of hydrogen is proportional to the mass of the metal hydride introduced in the annular tubes. Thus, more heat is 
generated in Case 1.c $\left(\mathrm{d}_{\mathrm{MeH}}=2.7 \mathrm{~cm}\right)$ and a larger complex hydride area reaches or even exceeds the required kinetics temperature $\left(130^{\circ} \mathrm{C}\right)$ which promotes the $\mathrm{CxH}$ charging process. Indeed, at $\mathrm{t}=240 \mathrm{~s}$, the hydrogen uptake is almost occurring throughout the entire zone of the complex hydride while for Cases 1.a, b, the temperature and the fraction of stored hydrogen continue their slow increase mainly close to the $\mathrm{MeH}$ annular tubes.

At $\mathrm{t}=720 \mathrm{~s}$, the $\mathrm{CxH}$ material reaches its equilibrium temperature $\left(230^{\circ} \mathrm{C}\right.$ at $\left.70 \mathrm{bar}\right)$ and the charging process of this material becomes thermally limited for the three studied cases. The hydrogen uptake is mainly occurring around the coolant tube where the temperature is the lowest whereas it has not even begun at the outer periphery of the reactor.

As time progresses from $720 \mathrm{~s}$ to $1800 \mathrm{~s}$, more $\mathrm{CxH}$ reaction heat is removed by the coolant and larger $\mathrm{CxH}$ saturated area can be observed around the heat exchange tube. Furthermore, there is more hydrogen uptake by the $\mathrm{CxH}$ material around the injection tubes in Cases 1.a, b compared to Case 1.c as it can be noted from the transformed fraction profile, $x$ at $\mathrm{t}=1800 \mathrm{~s}$ : a blue dashed line is added to distinguish between the two saturated areas ( $x_{\mathrm{MeH}}$ and $\left.x_{\mathrm{CxH}}=1\right)$. This is due to the fact that there is less $\mathrm{MeH}$ material introduced in the annular tubes when $\mathrm{d}_{\mathrm{MeH}}$ decreases $(0.7 \mathrm{~cm}$ and $1.7 \mathrm{~cm}$ in Cases 1.a, b compared to $2.7 \mathrm{~cm}$ in Cases 1.c). Therefore, the cooling effect of the hydrogen flowing through the injection tubes is more pronounced in the $\mathrm{CxH}$ area around the $\mathrm{MeH}$ tubes. As a result, the $\mathrm{CxH}$ temperature in this region falls below the equilibrium temperature which promotes the $\mathrm{CxH}$ reaction. For the rest of the $\mathrm{CxH}$ media, the large conduction path towards the cooling media inhibits a fast hydriding reaction.

The time evolution of weight fractions of stored hydrogen, $w_{f, \mathrm{CxH}}$ and $w_{f, \mathrm{MeH}}$ for Cases 1.a-c is presented in Fig. 3a. As described above, the increase of the MeH bed thickness improves the hydrogen storage rate at the beginning of the $\mathrm{CxH}$ charging process. Thereafter, the $\mathrm{CxH}$ reaction rate slows down due to the heat transfer limitation since the complex hydride bed reaches its equilibrium temperature as seen in Fig.2 for the three studied cases. Thus, the peripheral area of the complex hydride is equipped with another coolant tube and the resulting $\mathrm{CxH}$ reaction rate is determined for the three cases as shown in Fig. 3b. Cooling the peripheral area of the complex hydride bed does not affect the initiation of its charging process. It rather improves the thermal management of the complex hydride bed. Accordingly, a slight increase of $w_{f, \mathrm{CxH}}$ can be observed over time. The hydrogen loading rates of the three studied cases are almost overlapping at $1800 \mathrm{~s}$, corresponding to $81 \%$ of the maximum $\mathrm{CxH}$ hydrogen storage capacity, $w_{f, \mathrm{CxH}, \max }$.

For the metal hydride, it is clear from the time evolution of $w_{f, \text { MeH }}$ (Fig.3a) that the material reaches its saturated state after a few seconds of starting the absorption process. The difference between the maximum capacities, $w_{f, \mathrm{CxH}, \max }$ reached for the 
three studied cases is due to its dependence on the metal hydride bed temperature (See the expression of $w_{f, \mathrm{CxH}, \max }$ in Table 2).

Concluding, it can be stated that for the studied configuration, the increase of the $\mathrm{MeH}$ bed thickness does not significantly improve the $\mathrm{CxH}$ charging process, in particular at the initiation stage where the reaction is not yet thermally limited. On the other hand, it is worth noting that the idea of the combination reactor concept is to use the minimum of the metal hydride material necessary for the fast initiation of the $\mathrm{CxH}$ reaction. Therefore, it would be better to keep thin the thickness of the $\mathrm{MeH}$ annular tubes while increasing their number throughout the $\mathrm{CxH}$ media. This is the subject of the next section.

\subsection{Effect of the number and the arrangement of $\mathrm{MeH}$ and coolant tubes}

As described above, the hydrogen charging process in the combination reactor proceeds in two stages. First, the metal hydride starts to absorb hydrogen while releasing reaction heat which is used to initiate the charging process of the $\mathrm{CxH}$. Then, in the second stage, the uptake of $\mathrm{H}_{2}$ by the complex hydride continues to proceed. In this case, the $\mathrm{CxH}$ reaction heat should be efficiently dissipated by the cooling media. Otherwise, the temperature will reach the equilibrium, lowering then the $\mathrm{CxH}$ reaction rate.

Increasing the number of $\mathrm{MeH}$ and coolant tubes results in shorter conduction paths for both, metal and complex hydrides reaction heats. Therefore, a faster initiation stage of the $\mathrm{CxH}$ reaction and a better thermal management of the $\mathrm{CxH}$ bed could be expected. This is confirmed by the spatial evolution of temperature and transformed fraction of hydrogen shown in Fig. 4. The studied configurations and their geometrical parameters are presented in Fig. 1 and Table 1, respectively.

At $60 \mathrm{~s}$ in Case 3, the $\mathrm{MeH}$ reaction heat is distributed almost uniformly through the $\mathrm{CxH}$ media that has consequently reached almost everywhere the required $130{ }^{\circ} \mathrm{C}$ minimum temperature. As a result, faster $\mathrm{CxH}$ reaction rate can be observed in comparison with Cases 1.a and 2. Therefore, it takes in this case only $120 \mathrm{~s}$ for the hydrogen uptake to proceed overall the $\mathrm{CxH}$ media while the reaction still continues to occur slowly for the two other cases, mainly close to the MeH tubes.

As time progresses from $240 \mathrm{~s}$ to $720 \mathrm{~s}$, the generated thermal energy in Case 3 is continuously transferred towards the cooling media. Accordingly, more $\mathrm{CxH}$ material is transformed and reaches the saturated state. Therefore, the $\mathrm{CxH}$ temperature drops back to the coolant temperature, $T_{\text {cool }}$ except for the peripheral region, where it is still close to $230{ }^{\circ} \mathrm{C}$. This reflects the poor heat management in this area. Cases 1 and 2 continue to show a poor hydrogen uptake even after $1800 \mathrm{~s}$ due to the heat transfer limitation.

The behavior of the combination reactor described above is supported by the temporal evolution of the hydrogen loading rates presented in Fig. 5. At $t=120 \mathrm{~s}$, the weight fraction of stored hydrogen, $w_{f, \mathrm{CxH}}$ represents $46.87 \%, 18.12 \%$ and $4.68 \%$ of the 
maximum $\mathrm{CxH}$ hydrogen storage capacity, $w_{f, \mathrm{CxH}, \max }$ for Cases 1.a, 2 and 3, respectively. This is almost twice the stored fraction for Case $1 . c\left(\mathrm{~d}_{\mathrm{MeH}}=2.7 \mathrm{~cm}\right)$ at the same time (see Fig. 3). Thus, it is clear that the third configuration is the most advantageous for the initiation stage of the $\mathrm{CxH}$ charging process. However, after $120 \mathrm{~s}$, the hydrogen uptake becomes limited by the heat transfer, which explains the slow hydrogen loading rate and the long-time interval to fully charge the complex hydride (1800 s). For Cases 1 and 2, only $71 \%$ and $89 \%$ of $w_{f, \mathrm{CxH}, \max }$ are reached after the same time interval due to the combined effect of kinetics and heat transfer limitations.

The large length scale for heat transfer within the peripheral area of the complex hydride coupled with its low thermal conductivity contributes to the inefficient use of the storage media. Such problem could be addressed by cooling efficiently the external $\mathrm{CxH}$ zone or/and increasing the material thermal conductivity.

\subsection{Improvement of the combination reactor charging performance}

Since the metal hydride reaches its saturated state within few seconds of the charging process, this section is devoted to the optimization of the hydrogen uptake by the complex hydride and only results of $\mathrm{CxH}$ temperature and the related hydrogen loading rate are presented.

\subsubsection{Effect of adding coolant tubes in the peripheral $\mathrm{Cx} H$ area}

As a first attempt to improve the charging performance of the combination reactor, Cases 2 and 3 (see Fig. 1) are selected and their peripheral $\mathrm{CxH}$ area is equipped with coolant tubes as shown in Fig. 6. The temporal evolution of the average $\mathrm{CxH}$ bed temperature and the weight fraction of stored hydrogen, $w_{f, \mathrm{CxH}}$ are presented in the same graph.

For both cases, with and without addition of coolant tubes in the peripheral area, the peak of the average $\mathrm{CxH}$ temperature is reached at the same time. From that moment, the charging process is driven by the heat transfer and the role of the added heat exchange tubes comes into play to cool faster the complex hydride. As a result, the time required to fill the $\mathrm{CxH}$ media to $90 \%$ of its maximum hydrogen storage capacity decreases from more than $1800 \mathrm{~s}$ to $762 \mathrm{~s}$ in Case 2, and from $940 \mathrm{~s}$ to $348 \mathrm{~s}$ in Case 3, respectively.

\subsubsection{Effect of the CxH thermal conductivity}

In this study, a value of $0.35 \mathrm{~W} /(\mathrm{m} \mathrm{K})$ is used for the thermal conductivity of the complex hydride bed. However, higher values of $\mathrm{k}_{\mathrm{CxH}}(>10 \mathrm{~W} /(\mathrm{m} \mathrm{K})$ ) can be achieved by mixing the material with expanded natural graphite and compacting it in pellets as described in [23]. Thus, the dependence of the $\mathrm{CxH}$ charging process on the thermal conductivity is assessed and results are illustrated in Fig. 7 for the three studied configurations (Fig. 1). Based on the temporal evolution of the average $\mathrm{CxH}$ bed temperature and its hydrogen loading rate, three different behaviors of the $\mathrm{CxH}$ media are reported. 
In Case 1 , a slight increase of the $\mathrm{CxH}$ thermal conductivity, $k_{\mathrm{CxH}}$ delays the initiation of the $\mathrm{CxH}$ reaction by approximately $900 \mathrm{~s}$. This is due to the fact that the amount of the $\mathrm{MeH}$ reaction heat is not enough to bring the $\mathrm{CxH}$ media to the optimum temperature for the reaction kinetics. Indeed, kinetics measurements have shown that temperatures above $130{ }^{\circ} \mathrm{C}$ are required to reach high hydrogen loading rates [14]. Accordingly, an increase of the $\mathrm{CxH}$ thermal conductivity results in an overcooling of the $\mathrm{CxH}$ storage media since the $\mathrm{MeH}$ reaction heat is mainly conducted to the cooling media rather than heating the $\mathrm{CxH}$ media up to $130{ }^{\circ} \mathrm{C}$ and the charging process becomes limited by the kinetics.

The same trend is observed in Case 2 for higher values of $k_{\mathrm{CxH}}$; however the initiation of the $\mathrm{CxH}$ charging process is only delayed by $300 \mathrm{~s}$. Thereafter, the increase of $k_{\mathrm{CxH}}$ leads to better heat management of the $\mathrm{CxH}$ media and the time required to reach $90 \%$ of the maximum hydrogen storage capacity, $w_{f, \mathrm{CxH}, \max }$ is decreased to $718 \mathrm{~s}$ for $k_{\mathrm{CxH}}=10.5 \mathrm{~W} /(\mathrm{m} \mathrm{K})$. This result is comparable to the one obtained by the addition of the coolant tubes in the $\mathrm{CxH}$ peripheral region (Fig. 6). In this case, it is obvious that the $\mathrm{CxH}$ charging process is compromised by both, kinetics and heat transfer limitations.

In case 3 , the initiation of the $\mathrm{CxH}$ reaction is not affected anymore by the increase of $k_{\mathrm{CxH}}$ since a huge amount of $\mathrm{MeH}$ reaction heat is released due to the increase of the $\mathrm{MeH}$ annular tubes (49 MeH tubes in this case comparable to 9 in Case 1 and 25 in Case 2, see Table 1) and the charging process is only thermally limited. Therefore, the increase of $k_{\mathrm{CxH}}$ promotes an efficient use of the $\mathrm{CxH}$ storage media and it takes about $300 \mathrm{~s}$ to fill the complex hydride to $90 \%$ of its maximum hydrogen storage capacity for $k_{\mathrm{CxH}}=10.5$ $\mathrm{W} /(\mathrm{m} \mathrm{K})$.

\subsubsection{Combination of the two effects}

Based on the results presented above, it is clear that there is no need for further improvement of the heat management in Cases 1 and 2 since this leads to kinetics limitation of the $\mathrm{CxH}$ charging process. Thus, the third configuration is selected here to combine the effects of equipping the $\mathrm{CxH}$ peripheral area with coolant tubes and increasing the $\mathrm{CxH}$ thermal conductivity. The temporal evolution of the hydrogen loading rate resulting from such a combination reactor is shown in Fig. 8.

The main result is that in this case, the $\mathrm{CxH}$ media can be filled to $90 \%$ of its maximum hydrogen storage capacity after only $200 \mathrm{~s}$, a time interval competitive with the one achieved by a compressed gaseous storage system. It is interesting to note also that there is no need to increase the thermal conductivity, $k_{\mathrm{CxH}}$ more than $3.5 \mathrm{~W} /(\mathrm{m} \mathrm{K})$ and that the initiation stage of the $\mathrm{CxH}$ reaction is only slightly affected by the increase of this parameter. 
3.4. Impact on weight and volume constraints based on the forklift energy requirement

In order to determine the equivalence between electricity and hydrogen, most studies covered electric forklifts including Classes I, II and III with lift capacities ranging from $3,000 \mathrm{lb}$ to $20,000 \mathrm{lb}$ [5]. The energy use by a forklift is evaluated considering 8 hours of use per shift and a maximum of 3 shifts per day. Results vary depending on the efficiency of the fuel cell and the battery energy capacity used in calculations. Renquist et al. [24] reported a hydrogen consumption of $1.75 \mathrm{~kg} / \mathrm{shift} /$ forklift as an equivalence of $35 \mathrm{kWh}$ DC battery energy content/shift. Elgowainy et al. [4] used the equivalency of $15 \mathrm{kWh}$ at the wheels/fork to the consumption of $1 \mathrm{~kg} \mathrm{H}_{2}$ per fuel cell. Larriba et al [5] based their calculation on a discharge battery capacity of $80 \%$ per shift and determined the hydrogen tank capacity to be equal to $1.8 \mathrm{~kg} \mathrm{H}_{2}, 1.2 \mathrm{~kg} \mathrm{H}_{2}$ and $0.72 \mathrm{~kg} \mathrm{H}_{2}$ for Classes I, II and III forklifts, respectively.

In this study, the weight and volume of the hydrogen storage system, including the metal and complex hydrides, the hydrogen injection tubes and the stainless steel tubes, are calculated for the three classes of the forklift trucks based on the hydrogen tank capacities reported in [5]. Calculations are performed for the third configuration with and without addition of coolant tubes in the $\mathrm{CxH}$ peripheral area (Fig. 1 and Table 1, Case 3). Simulation results presented in Section 3.3 have proven the charging performance of those configurations, resulting in refueling times close or even less than 5 min. Fig. 9 illustrates their related weights and volumes depending on the energy fuel cell forklift requirement.

McWhorter et al [25] reported that a hydrogen system component with a $\mathrm{H}_{2}$ fuel capacity of $2.5 \mathrm{~kg}$ will require a minimum weight of $200 \mathrm{~kg}$ and a volume less than $230 \mathrm{l}$ to support a $10 \mathrm{~kW}$ fuel cell forklift vehicle. The calculated weights and volumes of the selected configurations presented in Fig. 9 are in line with those expectations. It should be noted here that the mass of the lids and the external tank wall as well as the material that could be used to improve the $\mathrm{CxH}$ thermal conductivity are not included in the calculations.

Nonetheless, it is relevant to note that for the selected configurations, the mass of the metal hydride is almost twice the mass of the complex hydride and the latter represents $66 \%$ of the total volume of the storage system, suggesting less interest to the combination of the two storage media. However, given the refueling time of $3 \mathrm{~min}$ achieved by the optimum configuration, such a complex reactor concept is attractive. Indeed, the simulation of the sorption process for the third configuration filled with pure $\mathrm{LaNi}_{4.3} \mathrm{Al}_{0.4} \mathrm{Mn}_{0.3}$ material and equipped with 96 coolant tubes has shown that it takes 452 s to reach $90 \%$ of the MeH maximum storage capacity (the result is not shown here), compared to $348 \mathrm{~s}$ and $200 \mathrm{~s}$ in the case of the combination reactor with the same number of coolant tubes, without and with improvement of the $\mathrm{CxH}$ thermal conductivity $\left(k_{C X H}=0.35\right.$ and $3.5 \mathrm{~W} /(\mathrm{m} \mathrm{K})$ respectively). This loading time is achieved 
when the $\mathrm{MeH}$ reactor, initially at room temperature of $22{ }^{\circ} \mathrm{C}$, is charged at 70 bar and the heat exchange fluid is flowing through the coolant tubes at $22{ }^{\circ} \mathrm{C}$ with a convective heat transfer coefficient, $h_{\text {cool }}$ of $220 \mathrm{~W} /\left(\mathrm{m}^{2} \mathrm{~K}\right)$. The thermal conductivity of the MeH material is set at $1.2 \mathrm{~W} /(\mathrm{m} \mathrm{K})$. Although shorter loading times for both, pure $\mathrm{MeH}$ and combination reactors could be expected by increasing $h_{c o o l}$ which means the increase of the coolant mass flux, this might be an issue since more energy will be required to pump the coolant through the heat exchanger tubes.

A better performance of the studied combination rector could be achieved by using the complex hydride material in pellet form which will improve its thermal conductivity, its density and its volumetric hydrogen capacity as discussed in [23].

It should be also emphasized that despite the increase of the $\mathrm{CxH}$ thermal conductivity $(10.5 \mathrm{~W} /(\mathrm{m} \mathrm{K})$ in Case 3 (Fig.7) and $3.5 \mathrm{~W} /(\mathrm{m} \mathrm{K})$ in Case 3 with the addition of coolant tubes in the $\mathrm{CxH}$ peripheral area (Fig.8)), a big number of coolant tubes is used to ensure the efficient heat management of the $\mathrm{CxH}$ bed $(72$ and 96 coolant tubes for the two selected cases, respectively). As a result, the mass of the $\mathrm{CxH}$ material is decreased compared to the $\mathrm{MeH}$ as shown in Fig.9. The use of radial fins could improve both, the mass and volumetric ratios of the $\mathrm{CxH}$ media by reducing the number of coolant tubes for the same range of $\mathrm{CxH}$ thermal conductivity. Such a behavior has been observed in the case of sodium alanate storage systems [20], [26] and a configuration of a combination reactor equipped with smaller number of coolant tubes and radial fins would be the object of a future study.

In addition, considering the growing interest to the high temperature proton exchange fuel cells (HT-PEMFCs) operating at a temperature range of $100-200{ }^{\circ} \mathrm{C}$ [27], the proposed complex hydride reactor concept is suitable since it allows the use of the high thermal energy produced from HT-PEMFCs.

\section{Conclusion}

In this paper, the commercial finite element software, COMSOL Multiphysics has been used to optimize the charging process of a hydrogen storage system based on the combination of $\mathrm{LaNi}_{4.3} \mathrm{Al}_{0.4} \mathrm{Mn}_{0.3}$ and Li-Mg-N-H materials. The studied configuration is a large cylindrical reactor embedded with a variable number of $\mathrm{MeH}$ and coolant tubes. Simulation results have shown that increasing the number of $\mathrm{MeH}$ and coolant tubes leads to better use of the storage media since it results:

- First, in more $\mathrm{MeH}$ reaction heat distributed uniformly through the $\mathrm{CxH}$ media which promotes the initiation stage of the $\mathrm{CxH}$ reaction.

- Second, in shorter heat conduction path towards the heat exchange fluid, ensuring an efficient heat management during the $\mathrm{CxH}$ reaction.

A refueling time of 15 min has been achieved for the configuration with $49 \mathrm{MeH}$ annular tubes of $0.7 \mathrm{~cm}$ of thickness and 72 coolant tubes of $1.4 \mathrm{~cm}$ of diameter. However, the spatial distribution of the corresponding $\mathrm{CxH}$ temperature has shown that the inefficient heat removal at the peripheral region of the complex hydride is 
responsible for the slow $\mathrm{CxH}$ hydriding process. Accordingly, two effects are considered, increasing the number of coolant tubes in this area or/and increasing the thermal conductivity of the complex hydride. Comparable refueling times of $5 \mathrm{~min}$ are obtained by considering these two effects separately whereas a charging time of almost $3 \mathrm{~min}$ is achieved by combining the two effects with a total number of 96 coolant tubes and a $\mathrm{CxH}$ thermal conductivity of $3.5 \mathrm{~W} /(\mathrm{m} \mathrm{K})$.

The optimum configuration of the combination reactor would be suitable for integration in fuel cell forklifts applications. In addition to the competitive refueling time compared to the high pressure hydrogen storage technology, the mass and volume of the optimum configuration are in line with the forklift trucks requirements in terms of weight and size. 


\section{Acknowledgments}

The research leading to these results has received funding from the European Union's Seventh Framework Programme (FP7/2007-2013) for the Fuel Cells and Hydrogen Joint Technology Initiative under grant agreement no. 256653.

M.B. would like to thank the German Academic Exchange Service (DAAD) for the DLRDAAD Research Fellowship. 


\section{References}

[1] Ahluwalia RK, Hua TQ, Peng JK. On-board and Off-board performance of hydrogen storage options for light-duty vehicles. Int J Hydrogen Energy 2012;37:2891-910.

[2] Kurtz J, Ainscough C, Simpson L, Caton M. Hydrogen Storage Needs for Early Motive Fuel Cell Markets 2012.

[3] Klebanoff L, Pratt J, Johnson T, Moreno M, Arienti M. Analysis of H 2 Storage Needs for Early Market Non-motive Fuel Cell Applications 2011.

[4] Elgowainy A, Gaines L, Wang M. Fuel-cycle analysis of early market applications of fuel cells: Forklift propulsion systems and distributed power generation. Int J Hydrogen Energy 2009;34:3557-70.

[5] Larriba T, Garde R, Santarelli M. Fuel cell early markets: Techno-economic feasibility study of PEMFC-based drivetrains in materials handling vehicles. Int J Hydrogen Energy 2013;38:2009-19.

[6] Oorja launches Model 1 DMFC as onboard battery charger for forklifts. Fuel Cells Bull 2010;2010:3.

[7] McConnell VP. Rapid refill, high uptime: running forklifts with fuel cells. Fuel Cells Bull 2010;2010:12-9.

[8] Lucas L. $\mathrm{H}_{2}$ Logic, Dantruck launch fuel cells for heavy-duty forklifts. Fuel Cells Bull 2011;2011:2-3.

[9] Power B. BMW, Linde MH and TUM to trial hydrogen forklifts, tow tractors. Fuel Cells Bull 2013;2013:3.

[10] Office M, Fuel Cell D. Air Liquide starts up hydrogen station for IKEA France forklifts. Fuel Cells Bull 2014;2014:7-8.

[11] Sandia project to speed up refueling of hydrogen forklifts. Fuel Cells Bull 2014;2014:6.

[12] Jain IP, Jain P, Jain A. Novel hydrogen storage materials: A review of lightweight complex hydrides. J Alloys Compd 2010;503:303-39.

[13] Bürger I, Komogowski L, Linder M. Advanced reactor concept for complex hydrides: Hydrogen absorption from room temperature. Int J Hydrogen Energy 2014;39:7030-41.

[14] Bürger I, Hu JJ, Vitillo JG, Kalantzopoulos GN, Deledda S, Fichtner M, Baricco M, Linder M. Material properties and empirical rate equations for hydrogen sorption reactions in $2 \mathrm{LiNH}_{2}-1.1 \mathrm{MgH}_{2}-0.1 \mathrm{LiBH}_{4}-3$ wt.\% $\mathrm{ZrCoH}_{3}$. Int J Hydrogen Energy 2014;39:8283-92. 
[15] Bhouri M, Bürger I, Linder M. Optimization of hydrogen charging process parameters for an advanced complex hydride reactor concept. Int J Hydrogen Energy 2014:1-14.

[16] Guo J, Yang J, Zhao Y, Pan X, Zhang L, Zhao L, Zheng J. Investigations on temperature variation within a type III cylinder during the hydrogen gas cycling test. Int J Hydrogen Energy 2014;39:13926-34.

[17] Wang G, Zhou J, Hu S, Dong S, Wei P. Investigations of filling mass with the dependence of heat transfer during fast filling of hydrogen cylinders. Int J Hydrogen Energy 2014;39:4380-8.

[18] Mohan G, Prakash Maiya M, Srinivasa Murthy S. Performance simulation of metal hydride hydrogen storage device with embedded filters and heat exchanger tubes. Int J Hydrogen Energy 2007;32:4978-87.

[19] Freni a., Cipitì F, Cacciola G. Finite element-based simulation of a metal hydridebased hydrogen storage tank. Int J Hydrogen Energy 2009;34:8574-82.

[20] Bhouri M, Goyette J, Hardy BJ, Anton DL. Sensitivity study of alanate hydride storage system. Int J Hydrogen Energy 2011;36:621-33.

[21] Bao Z, Wu Z, Nyamsi SN, Yang F, Zhang Z. Three-dimensional modeling and sensitivity analysis of multi-tubular metal hydride reactors. Appl Therm Eng 2013;52:97-108.

[22] Na Ranong C, Lozano G, Hapke J, Roetzel W, Fieg G, Bellosta von Colbe J. Application of Danckwerts-type boundary conditions to the modeling of the thermal behavior of metal hydride reactors. Chem Eng Sci 2011;66:4654-62.

[23] Pohlmann C, Röntzsch L, Weißgärber T, Kieback B. Heat and gas transport properties in pelletized hydride-graphite-composites for hydrogen storage applications. Int J Hydrogen Energy 2013;38:1685-91.

[24] Renquist J V., Dickman B, Bradley TH. Economic comparison of fuel cell powered forklifts to battery powered forklifts. Int J Hydrogen Energy 2012;37:12054-9.

[25] McWhorter S, Read C, Ordaz G, Stetson N. Materials-based hydrogen storage: Attributes for near-term, early market PEM fuel cells. Curr Opin Solid State Mater Sci 2011;15:29-38.

[26] Hardy BJ, Anton DL. Hierarchical methodology for modeling hydrogen storage systems. Part II: Detailed models. Int J Hydrogen Energy 2009;34:2992-3004.

[27] Chandan A, Hattenberger M, El-kharouf A, Du S, Dhir A, Self V, Pollet B.G., Ingram A, Bujalski W. High temperature (HT) polymer electrolyte membrane fuel cells (PEMFC) - A review. J Power Sources 2013;231:264-78. 
Fig.1 - Geometries of the three studied configurations of the combination reactor with different numbers of $\mathrm{MeH}$ and coolant tubes.

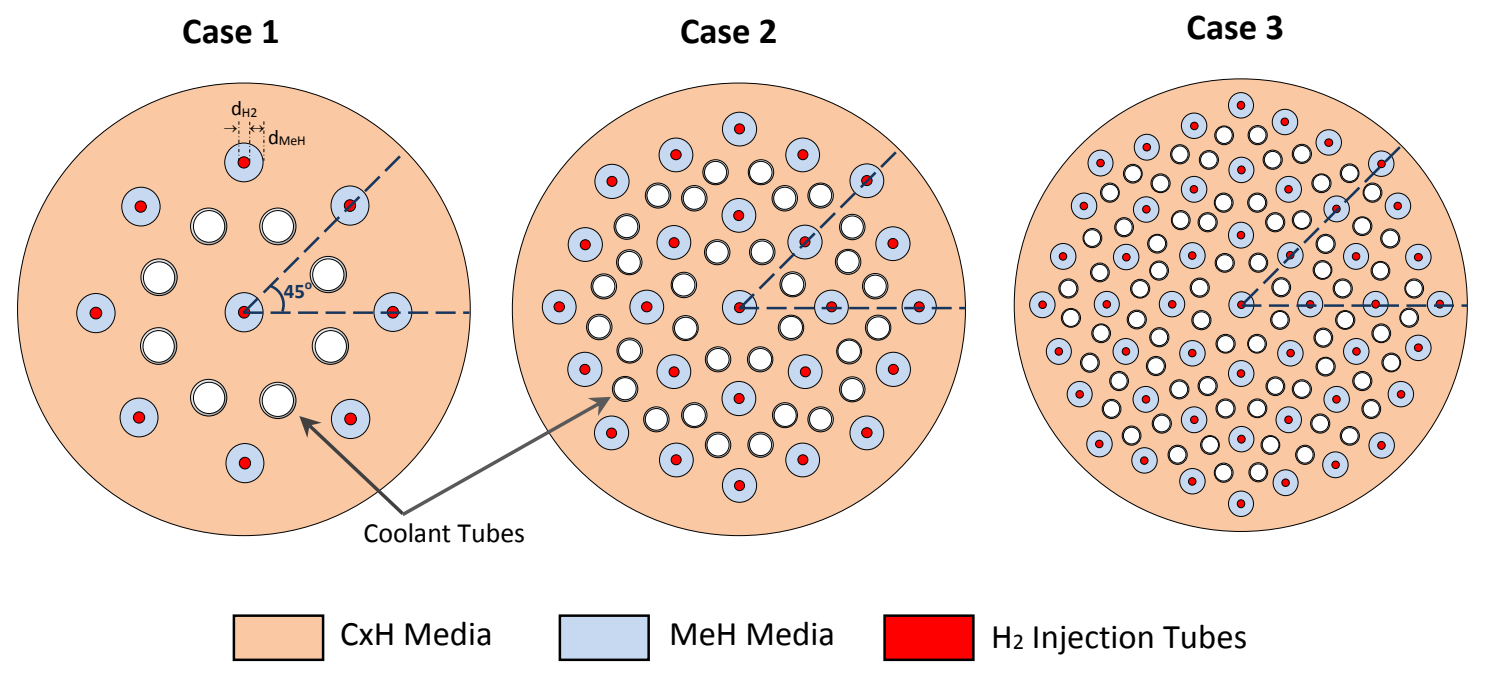


Fig.2 - Evolution of temperature and transformed fraction of hydrogen for the first configuration with different thicknesses of $\mathrm{MeH}$ tubes at selected times.

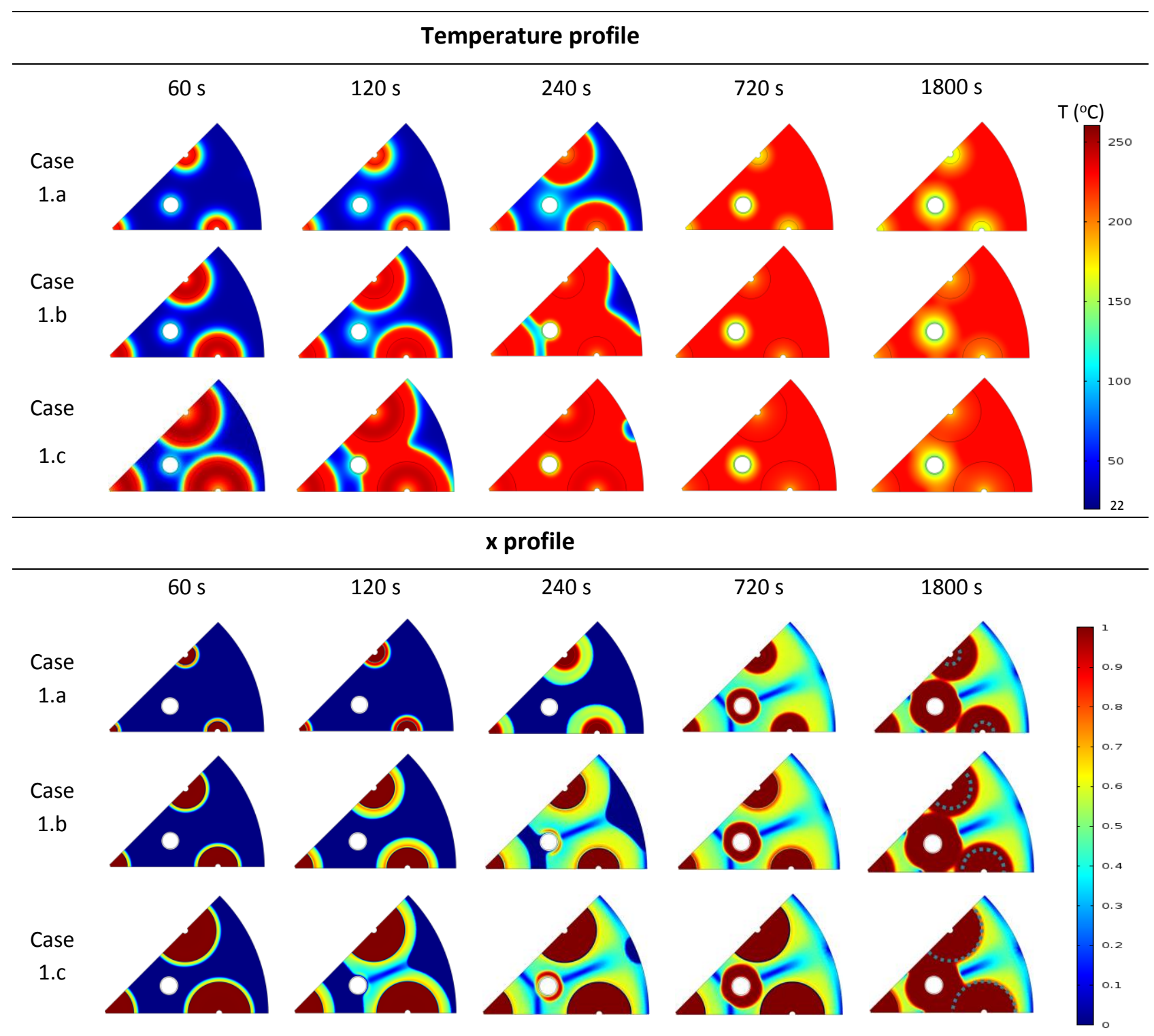


Fig.3 - Effect of the thickness of MeH tubes on the charging process (a) without and (b) with additional coolant tube for the first configuration.
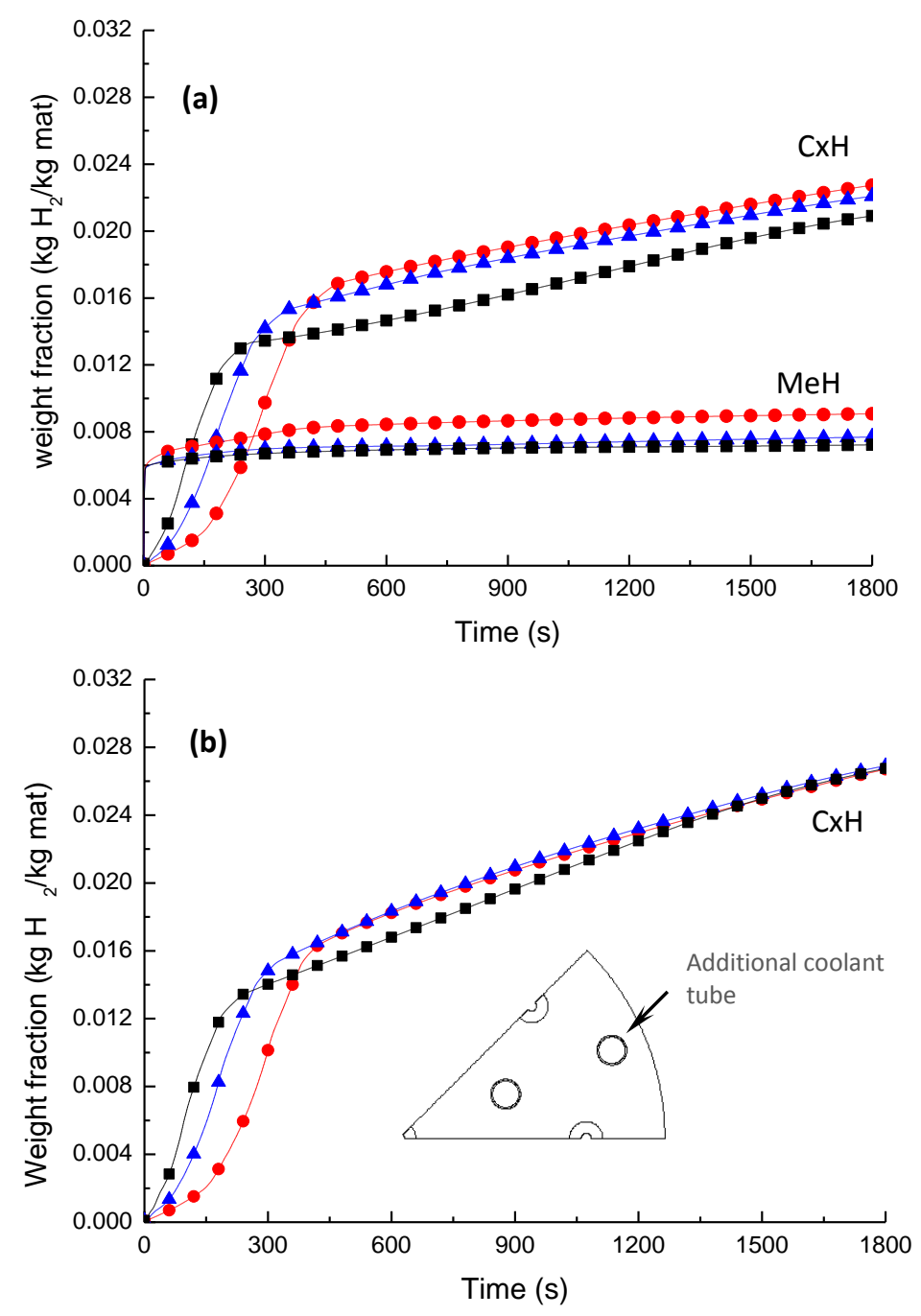

- Case 1.a, $\Delta$ Case 1.b, $\mathbf{a}$ Case 1.c 
Fig.4 - Evolution of temperature and transformed fraction of hydrogen for the three studied configurations with different numbers of $\mathrm{MeH}$ and coolant tubes at selected times.

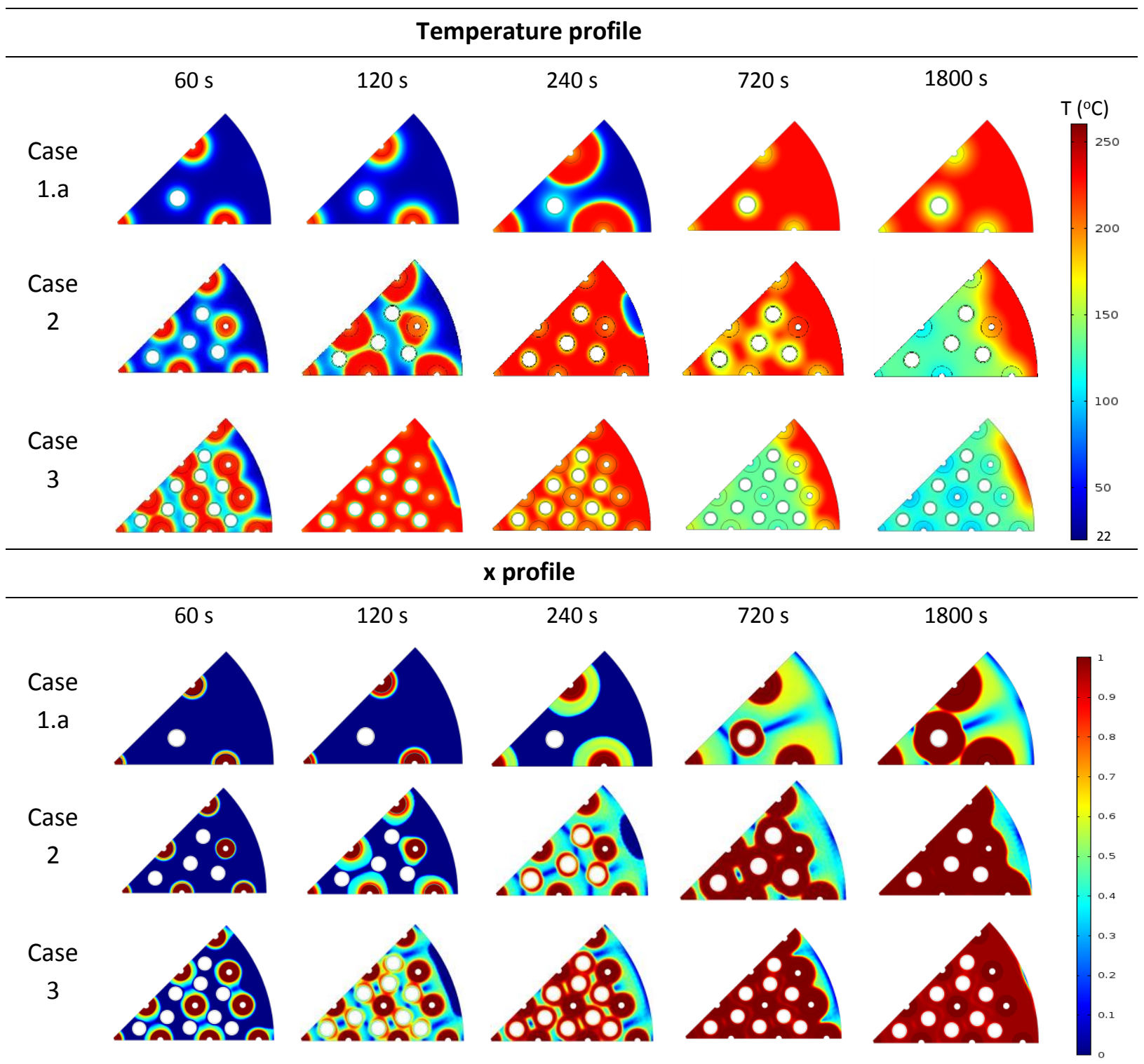


Fig.5 - Effect of the number of $\mathrm{MeH}$ and coolant tubes on the charging process for the three studied configurations.

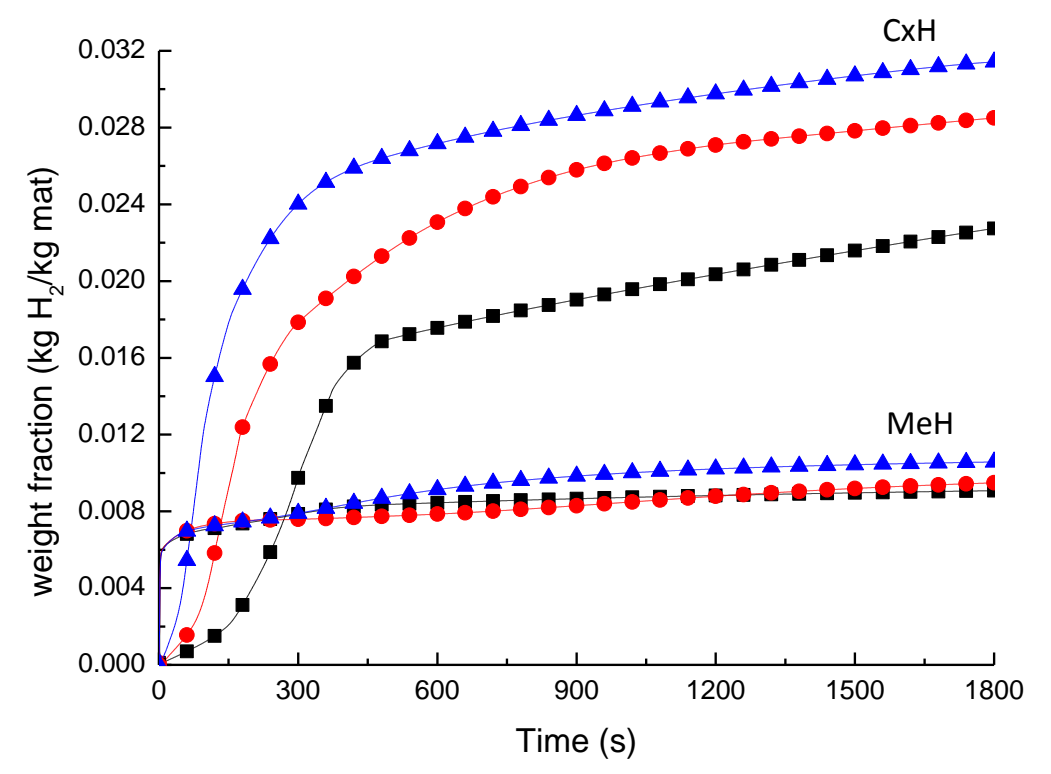

- Case 1.a, $\bigcirc$ Case 2, $\boldsymbol{\Delta}$ Case 3 
Fig.6 - Effect of the addition of coolant tubes in the $\mathrm{CxH}$ peripheral area on its charging process for the second and third configurations.
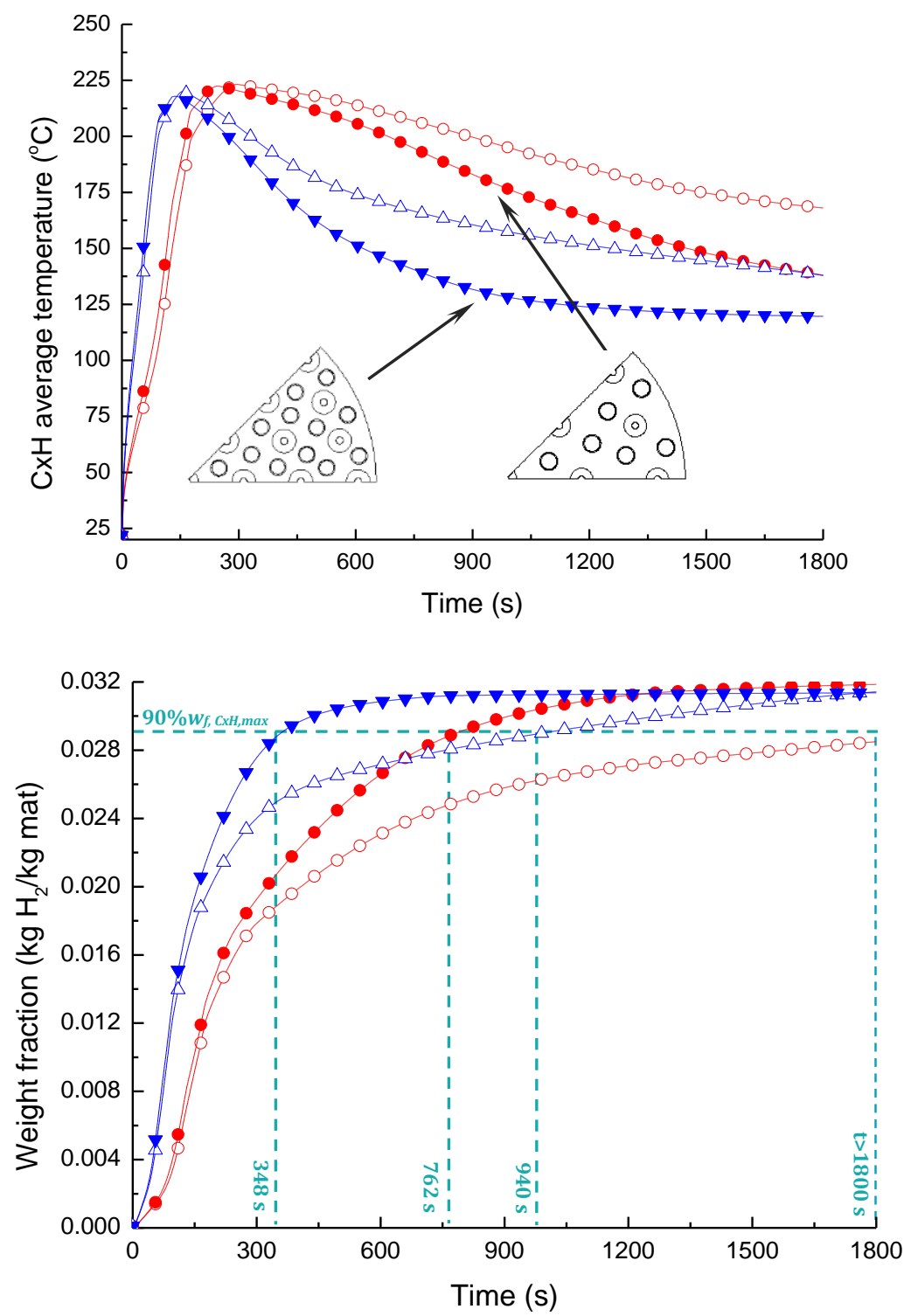

Case $2 \bigcirc$ without

Case $3 \begin{gathered}\Delta \text { without } \\ \nabla \text { with }\end{gathered}$ 
Fig.7 - Effect of the complex hydride thermal conductivity on the $\mathrm{CxH}$ charging process for the three studied configurations.
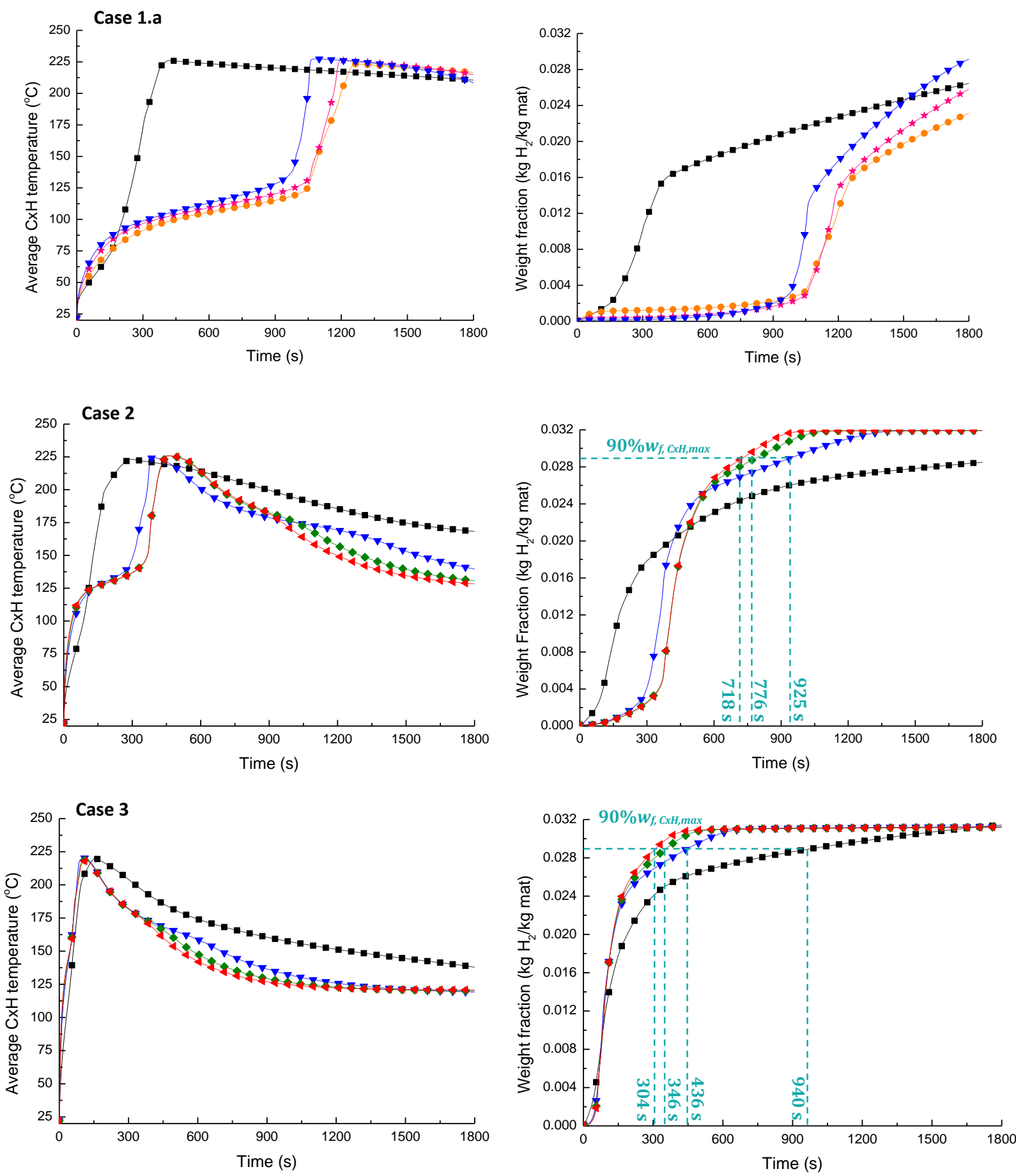

- $k_{\mathrm{CxH}}=0.35 \mathrm{~W} /(\mathrm{m} \mathrm{K}), \diamond k_{\mathrm{CxH}}=0.70 \mathrm{~W} /(\mathrm{m} \mathrm{K}), \star k_{\mathrm{CxH}}=1.75 \mathrm{~W} /(\mathrm{m} \mathrm{K})$,

$\nabla k_{\mathrm{CxH}}=3.50 \mathrm{~W} /(\mathrm{m} \mathrm{K}), \diamond k_{\mathrm{CxH}}=7.00 \mathrm{~W} /(\mathrm{m} \mathrm{K}), \triangleleft k_{\mathrm{CxH}}=10.50 \mathrm{~W} /(\mathrm{m} \mathrm{K})$. 
Fig.8 - Combined effects of increasing the $\mathrm{CxH}$ thermal conductivity and adding coolant tubes in the $\mathrm{CxH}$ peripheral area for the third configuration.

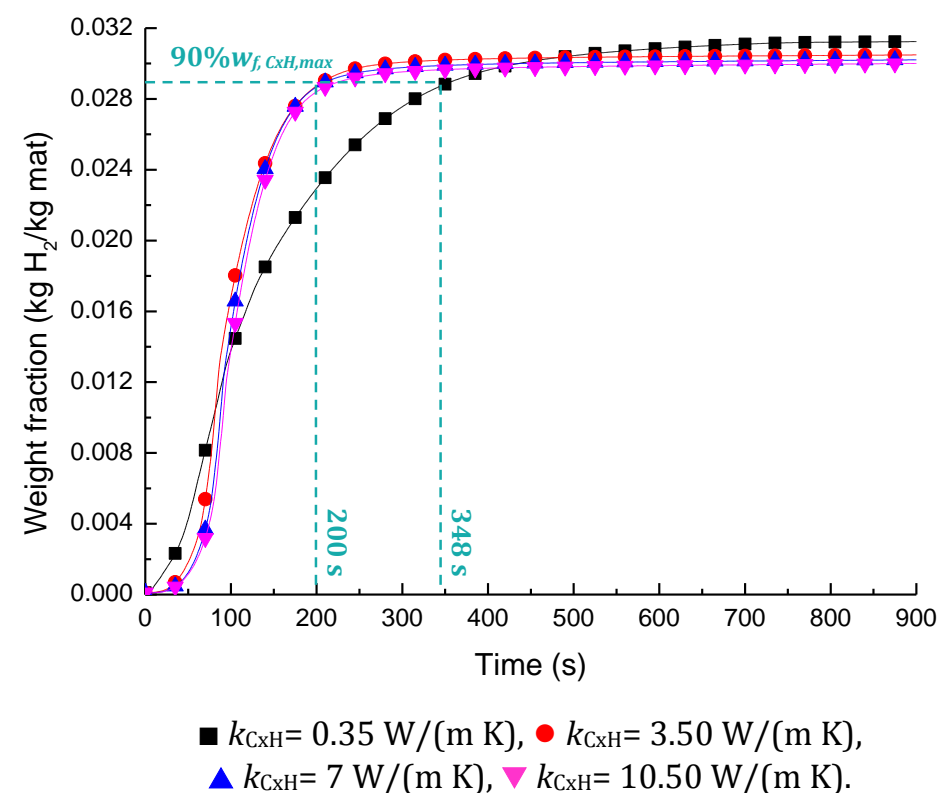


Fig.9 - Weight and volume of the optimum configurations of the combination reactor depending on the fuel cell forklifts energy requirements.
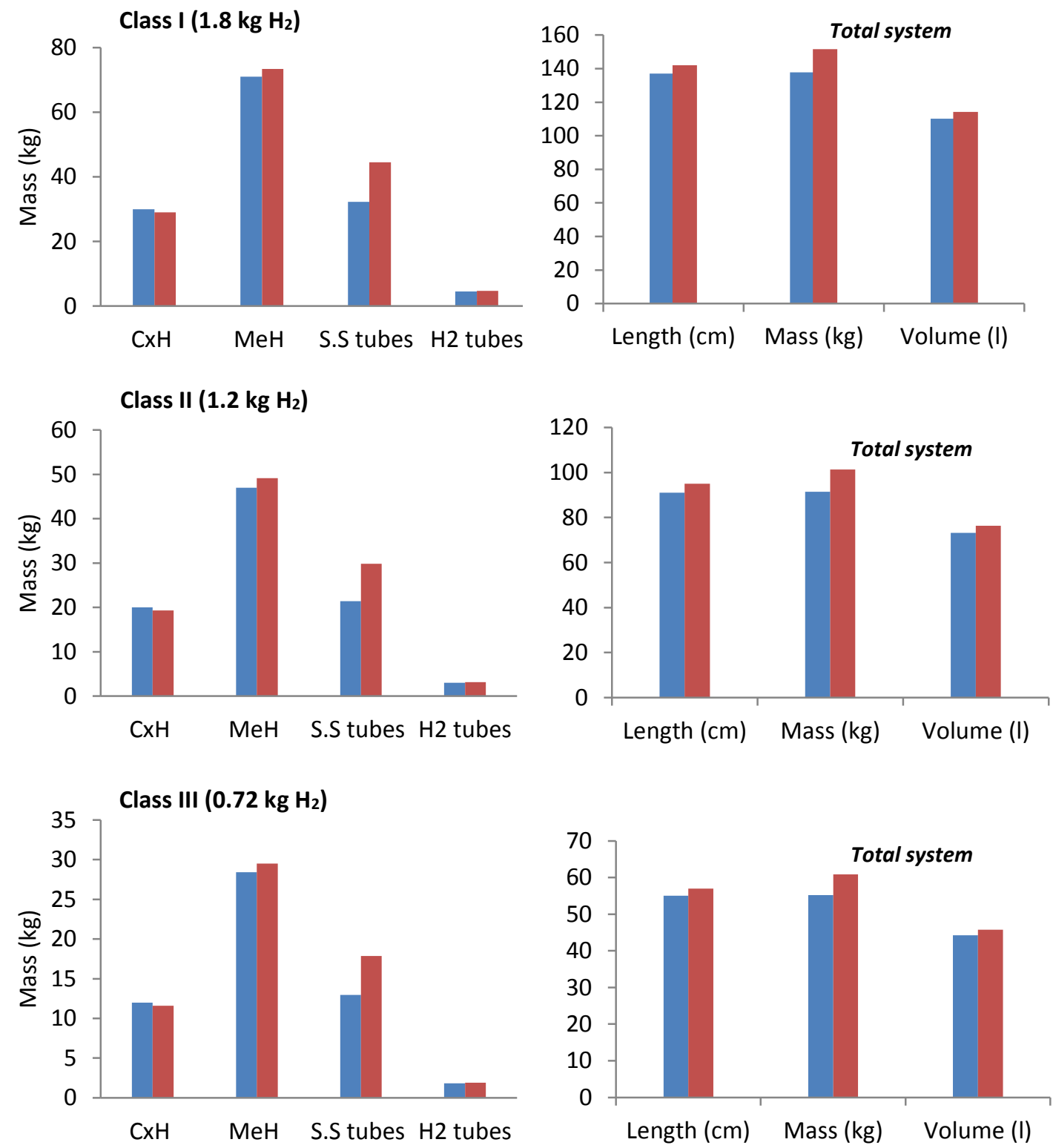

घithout additional coolant tubes $\quad$ with additional coolant tubes 
Table 1 - Details of the combination reactor geometries

\begin{tabular}{|c|c|c|c|c|c|}
\hline & \multicolumn{3}{|c|}{ Case 1} & \multirow{2}{*}{ Case 2} & \multirow{2}{*}{ Case 3} \\
\hline & $\mathbf{a}$ & b & $\mathbf{c}$ & & \\
\hline Inner diameter of combination reactor $(\mathrm{cm})$ & & & & 32 & \\
\hline Diameter of $\mathrm{H}_{2}$ injection tubes $(\mathrm{cm})$ & & & & 0.6 & \\
\hline Metal hydride thickness (cm) & 0.7 & 1.72 & 2.7 & 0.7 & 0.7 \\
\hline Diameter of coolant tubes $(\mathrm{cm})$ & & 1.8 & & 1.6 & 1.4 \\
\hline Coolant tube wall thickness (cm) & & & & 0.1 & \\
\hline Number of $\mathrm{H}_{2}$ injection tubes & & 9 & & 25 & 49 \\
\hline Number of coolant tubes & & 16 & & $32 / 41$ & $72 / 96$ \\
\hline
\end{tabular}


Table 2 - Input data for simulations [13]

Parameter

$\mathbf{L a N i}_{4.3} \mathbf{A l}_{0.4} \mathbf{M n}_{0.3}$ material (MeH)

Arrhenius parameter for abs $\left(\mathrm{s}^{-1}\right)$

Activation energy for abs $\left(\mathrm{J} \mathrm{mol}^{-1} \mathrm{~K}^{-1}\right)$

Enthalpy of absorption reaction ( $\left.\mathrm{J} \mathrm{mol}^{-1}\right)$

Entropy of absorption reaction $\left(\mathrm{J} \mathrm{mol}^{-1} \mathrm{~K}^{-1}\right)$

Specific heat capacity $\left(\mathrm{J} \mathrm{kg}^{-1} \mathrm{~K}^{-1}\right)$

Material density $\left(\mathrm{kg} \mathrm{m}^{-3}\right)$

Thermal conductivity $\left(\mathrm{W} \mathrm{m}^{-1} \mathrm{~K}^{-1}\right)$

Permeability $\left(\mathrm{m}^{2}\right)$

Max. gravimetric $\mathrm{H}_{2}$ storage capacity (wt.\%)

\section{Li-Mg-N-H material (CxH)}

Arrhenius parameter for abs, $1^{\text {st }}$ step $\left(\mathrm{s}^{-1}\right)$

Arrhenius parameter for abs, $2^{\text {nd }}$ step $\left(\mathrm{s}^{-1}\right)$

Activation energy for abs, $1^{\text {st }}$ step $\left(\mathrm{J} \mathrm{mol}^{-1} \mathrm{~K}^{-1}\right)$

Activation energy for abs, $2^{\text {nd }}$ step $\left(\mathrm{J} \mathrm{mol}^{-1} \mathrm{~K}^{-1}\right)$

Enthalpy of absorption reaction $\left(\mathrm{J} \mathrm{mol}^{-1}\right)$

Entropy of absorption reaction $\left(\mathrm{J} \mathrm{mol}^{-1} \mathrm{~K}^{-1}\right)$

Specific heat capacity $\left(\mathrm{J} \mathrm{kg}^{-1} \mathrm{~K}^{-1}\right)$

Material density $\left(\mathrm{kg} \mathrm{m}^{-3}\right)$

Thermal conductivity $\left(\mathrm{W} \mathrm{m}^{-1} \mathrm{~K}^{-1}\right)$

Permeability $\left(\mathrm{m}^{2}\right)$

Max. gravimetric $\mathrm{H}_{2}$ storage capacity (wt.\%)

Porosity (MeH, $\mathrm{CxH})$

\section{Heat transfer}

Specific heat capacity of steel $\left(\mathrm{J} \mathrm{kg}^{-1} \mathrm{~K}^{-1}\right)$

Density of steel $\left(\mathrm{kg} \mathrm{m}^{-3}\right)$

Thermal conductivity of steel ( $\left.\mathrm{W} \mathrm{m} \mathrm{m}^{-1} \mathrm{~K}^{-1}\right)$

Coolant temperature $\left({ }^{\circ} \mathrm{C}\right)$

Heat transfer coefficient for coolant $\left(\mathrm{W} \mathrm{m}^{-2} \mathrm{~K}^{-1}\right)$

Hydrogen temperature in the injection tube $\left({ }^{\circ} \mathrm{C}\right)$

Heat transfer coefficient for $\mathrm{H}_{2}$ in injection tubes $\left(\mathrm{W} \mathrm{m}^{-2} \mathrm{~K}^{-1}\right)$
Symbol

Value

$\begin{array}{cc}A_{a, \mathrm{MeH}} & 100 \\ E_{A, \mathrm{MeH}} & 21,000 \\ \Delta H_{a, \mathrm{MeH}} & -35,940 \\ \Delta S_{a, \mathrm{MeH}} & -98.58 \\ C_{p, \mathrm{MeH}} & 420 \\ \rho_{\mathrm{MeH}} & 8,200 \\ k_{\mathrm{MeH}} & 1.2 \\ \mathrm{~K} & 1 \times 10^{-12}\end{array}$

$w_{f, \mathrm{MeH}, \max }$

$\left(1.2126-0.0003 T\left[^{\circ} \mathrm{C}\right]\right.$

$\left.-9.10^{-6} T^{2}\left[{ }^{\circ} \mathrm{C}^{2}\right]\right) / 100$

$\begin{array}{cc}A_{a, \mathrm{CxH}, 1} & 2.729 \times 10^{17} \\ A_{a, \mathrm{CxH}, 2} & 4.678 \times 10^{14} \\ E_{A, \mathrm{CxH}, 1} & 164,800 \\ E_{A, \mathrm{CxH}, 2} & 147,800 \\ \Delta H_{a, \mathrm{CxH}} & -38,000 \\ \Delta S_{a, \mathrm{CxH}} & -111 \\ C_{p, \mathrm{CxH}} & 1,533 \\ \rho_{\mathrm{CxH}} & 900 \\ k_{\mathrm{CxH}} & 0.35 \\ \mathrm{~K} & 1 \times 10^{-12} \\ w_{f, \mathrm{CxH}, \max } & 3.2 \\ \varepsilon & 0.55\end{array}$

$C_{p, \mathrm{~S} . \mathrm{S}}$

500

$\rho_{\mathrm{S} . \mathrm{S}}$

8,000

$k_{\mathrm{S} . \mathrm{S}}$

15

$T_{\text {cool }}$

130

$h_{\text {cool }}$

220

$T_{H_{2}} \quad 22$

$h_{\mathrm{H}_{2}}$

50

\section{Hydrogen gas}

Coefficient, van der Waals equation ( $\left.\mathrm{Pa} \mathrm{m}^{6} \mathrm{~mol}^{-2}\right)$

a

0.025

Coefficient, van der Waals equation $\left(\mathrm{m}^{3} \mathrm{~mol}^{-1}\right)$

$b$

$2.66 \times 10^{-5}$

molecular weight of gas $\left(\mathrm{g} \mathrm{mol}^{-1}\right)$

Gas constant $\left(\mathrm{J} \mathrm{mol}^{-1} \mathrm{~K}^{-1}\right)$

$M_{H_{2}}$

2.016

Dynamic viscosity (Pa s)

$R$

8.314

Heat capacity $\left(\mathrm{J} \mathrm{kg}^{-1} \mathrm{~K}^{-1}\right)$

$\mu_{g}$

$10^{-5 \times 9.05 \times(\mathrm{T} / 293)^{0.68}}$

$C_{p, g}$

14,304 